\title{
Penggunaan Model Studysaster pada Pembelajaran Daring dalam Upaya Meningkatkan Hasil Belajar Bahasa Indonesia pada Siswa Kelas 5 SD Kyai Ibrahim Surabaya Tahun Pelajaran 2020-2021
}

\author{
Diterima: \\ 5 Juni 2021 \\ Revisi: \\ 27 Juli 2021 \\ Terbit:
}

1 Februari 2022

\author{
Bety Indri Puspitarini \\ SD Kyai Ibrahim Surabaya \\ Surabaya, Indonesia \\ E-mail: bety.indri1706@gmail.com
}

\begin{abstract}
Abstrak - Menghadapi dampak pandemi covid-19, kementerian Pendidikan dan kebudayaan melakukan penyesuaian, salah satunya adalah bekerja dari rumah dan belajar dari rumah. Melalui penggunaan model studysaster dalam pembelajaran, siswa dapat mengedukasi dirinya sendiri dan dapat mengedukasi orang lain dari karya yang telah dibuat. Dengan begitu siswa mendapatkan suatu bekal untuk kehidupan dalam menghadapi suatu bencana dari dampak yang ditimbulkan. Dalam upaya ini guru sebagai fasilitator dan motivator yang diperlukan siswa dalam proses pembelajaran mengadakan penelitian tindakan kelas dengan menggunakan model pembelajaran studysaster dalam penyusunan RPP. Berdasarkan hasil yang didapat pada siklus I dan II dapat disimpulkan bahwa kemampuan siswa mengalami peningkatan dari $57 \%$ menjadi $75 \%$. Adanya peningkatan hasil pembelajaran tersebut dikarenakan guru menggunakan model pembelajaran studysaster pada pembelajaran Bahasa Indonesia materi iklan media cetak dan elektronik. Model pembelajaran yang digunakan oleh guru ternyata memiliki dampak atau pengaruh yang positif dalam upaya peningkatan hasil belajar siswa. Hal ini dapat dilihat dari tingkah laku atau sikap siswa ketika mengikuti pembelajaran siswa terlihat aktif dan menikmati proses pembelajaran tersebut. Pada siklus II ini diperoleh ketuntasan klasikal sebesar $81 \%$ melebihi batas minimal ketuntasan klasikal yang telah ditentukan sebelumnya sebesar $75 \%$.
\end{abstract}

Kata Kunci - model studysaster, pembelajaran daring, hasil belajar

Abstract - acing the impact of the COVID-19 pandemic, the Ministry of Education and Culture has made adjustments, one of which is working from home and studying from home. Through the use of the studysaster model in learning, students can educate themselves and can educate others from the work that has been made. That way students get a provision for life in the face of a disaster from the impact it has. In this effort the teacher as a facilitator and motivator needed by students in the learning process conducts classroom action research using the studysaster learning model in the preparation of lesson plans. Based on the results obtained in cycles I and II, it can be concluded that the ability of students has increased from $57 \%$ to $75 \%$. The increase in learning outcomes is due to the teacher using the studysaster learning model in Indonesian learning of printed and electronic media advertising materials. The learning model used by the teacher turned out to have a positive impact or influence in an effort to improve student learning outcomes. This can be seen from the behavior or attitudes of students when participating in learning, students look active and enjoy the learning process. In the second cycle, classical completeness was obtained by $81 \%$, exceeding the previously determined minimum limit of classical completeness of $75 \%$.

Keywords - studysaster model, online learning, learning outcomes 
PTK, Vol.2 No.2 2022

ISSN: 2747-1977 (Print) / 2747-1969 (Online)

DOI: https://doi.org/10.53624/ptk.v2i2.53

\section{PENDAHULUAN}

Maju atau tidaknya sebuah negara dapat di lihat dari pendidikan negara tersebut. Negaranegara yang maju telah membuktikan, bahwa pendidikan mempunyai kontribusi yang sangat penting dalam meningkatkan kualitas bangsanya. Pendidikan adalah sumber dari segala sumber kemajuan suatu bangsa, karena dengan melalui pendidikan kualitas sumber daya manusia suatu bangsa tersebut dapat ditingkatkan.

Kualitas sumber daya manusia dapat ditingkatkan melalui pendidikan, hal ini dibuktikan pengalaman empiris oleh beberapa negara yang maju dapat menikmati kesejahteraan dan kemakmuran bagi rakyatnya. Negara-negara ini memulai pembangunan melalui pendidikan meskipun dapat dikatakan negara-negara maju tersebut tidak memiliki sumber daya alam yang cukup. Salah satu usaha yang dilakukan oleh negara-negara yang maju melalui peningkatan sumber daya manusia, dengan sumber daya yang berkualitas dapat mampu menguasai ilmu pengetahuan dan teknologi. Beberapa negara-negara yang maju tersebut antara lain : Jepang, Taiwan, Korea Selatan, Cina, Singapura, Thailand, Vietnam dan sebagainya. Sebagai contoh keberhasilan negara Singapura dalam pendidikan didukung dengan komitmen penuh oleh pemerintah yang memangkas birokrasi pendidikan. Ini ini menunjukkan pentingnya kesungguhan pemerintah dalam mendukung keberhasilan pendidikan karena keberhasilan pendidikan suatu bangsa merupakan salah satu parameter keberhasilan pemerintahan suatu negara.

Setiap warga negara memiliki hak untuk mendapatkan pendidikan yang layak. Dengan pendidikan dapat membuat kehidupan menjadi lebih sejahtera. Pemberlakuan pendidikan dasar secara gratis ini diambilkan dari sektor perolehan dana dari Anggaran Pendapatan Belanja Negara dan Anggaran Pendapatan Belanja Daerah sebesar 20\%, jadi diharapkan adanya kerjasama antara pemerintah pusat dan pemerintah daerah untuk menyelenggarakan pemenuhan pendidikan dasar bagi warga negara Indonesia (Sujatmoko 2010). Pendidikan yang baik adalah pendidikan yang dapat merubah tingkah laku sesuai nilai-nilai Pancasila, menggali potensi, meningkatkan kompetensi dalam berbagai kondisi dan situasi, baik dalam situasi yang mendukung ataupun tidak. Pendidikan harus dapat tetap dilaksanakan dalam kondisi apapun baik itu yang pengaruhi oleh keadaan geografis ataupun bencana alam.

Proses belajar dikatakan efektif jika mampu menfasilitasi siswa mencapai hasil belajar yang optimal. Menurut Purwanto hasil belajar adalah perubahan perilaku peserta didikakibat belajar. Perubahan perilaku disebabkan karena dia mencapai penguasaan atas sejumlah bahan yang diberikan dalam proses belajar mengajar. Lebih lanjut lagi Purwanto 
mengatakanbahwa hasil belajar dapat berupa perubahan dalam aspek kognitif, afektif, dan psikomotorik (S and Winata 2018). Di samping itu, Hamalik hasil belajar adalah perubahan tingkah laku pada seseorang yang dapat diamati dan diukur dalam bentuk pengetahuan, sikap, dan keterampilan (S and Winata 2018).

Pada awal bulan Maret pemerintah mengumumkan 2 kasus positif covid-19 di Indonesia. Virus covid-19 sangat mudah sekali menular sehingga pemerintah melakukan berbagai kebijakan untuk memutus mata rantai penyebaran virus covid-19 salah satunya adalah social distancing yakni himbauan untuk menjaga jarak di antara masyarakat, menjauhi aktivitas dalam masyarakat, segala bentuk kerumunan sehingga dapat menekan dari dampak yang ditimbulkan, karena tidak sedikit orang yang meninggal akibat virus tersebut.

Menghadapi dampak dari pandemi covid-19 yang bertambah parah, kementerian Pendidikan dan kebudayaan (KEMDIKBUD) melakukan penyesuaian pembelajaran, salah satunya adalah WFH yaitu Work From Home yang artinya bekerja dari rumah dan SFH yaitu School From Home yang artinya belajar dari rumah. Dengan adanya pembatasan interaksi, kementerian pendidikan di Indonesia juga mengeluarkan kebijakan yaitu dengan meliburkan sekolah dan mengganti proses kegiatan belajar dengan menggunakan sistem dalam jaringan (Daring). Menurut data update tercatat sejak pukul 12.00 WIB pada Sabtu, 27 Maret 2021 dari Liputan6.com, Jakarta, Satuan Tugas penanganan covid 19 melaporkan total akumulatif angka penambahan kasus meninggal dunia adalah 40.449 jiwa. Penyakit ini ini dapat menular dengan sangat mudah tanpa mengenal usia, oleh karena itu diperlukan upaya untuk mencegah penularan covid-19, salah satunya adalah dengan menggunakan model pembelajaran studysaster yang mana model pembelajaran ini bertujuan untuk mengedukasi, mengembangkan potensi, pengetahuan dan keterampilan peserta didik tentang bahayanya dari dampak yang ditimbulkan oleh bencana alam dan dapat mencari cara pencegahannya. Di era pandemi covid 19 menuntut guru untuk melakukan pengembangan strategi pembelajaran, bahan ajar atau media pembelajaran, dengan keterbatasan sarana dan prasarana untuk mencapai ketercapaian belajar daring (Nurhasanah et al. 2020).

Melalui penggunaan model studysaster dalam pembelajaran, peserta didik tidak hanya mengedukasi dirinya sendiri tetapi dapat mengedukasi orang lain dari karya yang telah dibuat. Model pembelajaran studysaster adalah model pembelajaran yang bertujuan mengedukasi siswa tentang bencana (dalam hal ini Covid-19) dan mampu menghasilkan produk. Nama studysaster diambil dari akronim "study" yang dalam bahasa Indonesia berarti belajar dan "disaster" yang berarti bencana Fitroni (Widyasari, 2020). Strategi pembelajaran ini lebih berorientasi pada proses belajar. Dalam konteks ini pula peserta didik perlu memahami apa makna belajar, manfaat apa saja yang diperoleh. Dengan begitu siswa mendapatkan suatu bekal untuk 
PTK, Vol.2 No.2 2022

ISSN: 2747-1977 (Print) / 2747-1969 (Online)

DOI: https://doi.org/10.53624/ptk.v2i2.53

kehidupan dalam menghadapi suatu bencana dari dampak yang ditimbulkan salah satunya adalah cara pencegahan. Sehingga peserta didik memiliki keterampilan hidup tentang pentingnya kesehatan dan empati. Dalam upaya ini guru sebagai fasilitator dan motivator yang diperlukan siswa dalam proses pembelajaran mengadakan penelitian tindakan kelas dengan judul Penggunaan Model Studysaster Pada Pembelajaran Daring Dalam Upaya Meningkatkan Hasil Belajar Bahasa Indonesia Materi Iklan Media Cetak dan Elektronik Pada Siswa Kelas 5 SD Kyai Ibrahim Surabaya Tahun Pelajaran 2020-2021.

\section{METODE}

A. Subyek, Tempat, dan Waktu Penelitian

1. Subyek Penelitian

Subyek penelitian adalah siswa kelas 5 SD Kyai Ibrahim Surabaya tahun pelajaran 20202021, dengan jumlah siswa 28 orangyang terdiri dari 16 siswa laki-laki dan 12 siswa perempuan dengan rentang usia 11-12 tahun. Kondisi ekonomi menengah ke bawah, pendidikan orang tua sebagian lulusan sarjana dan sebagian lagi lulusan SMA.

2. Tempat Penelitian

Penelitian dilaksanakan di SD Kyai Ibrahim Surabaya, jalan Siwalankerto III no 15, Wonocolo-Surabaya Selatan.

3. Waktu Penelitian

Waktu penelitian disesuaikan dengan kegiatan pembelajaran untuk materi iklan media cetak atau elektronik pelajaran bahasa Indonesia pada semester 2 tahun pelajaran 2020-2021 dengan jadwal sebagai berikut:

a. Siklus 1 terdiri dari 1 kali pertemuan, dilaksanakan (2x35 menit) pada hari Selasa tanggal 12 Januari 2021.

b. Siklus 2 terdiri dari 1 kali pertemuan, dilaksanakan (3x35 menit) pada hari Rabu tanggal 13 Januari 2021.

B. Desain Prosedur Perbaikan Penelitian Pembelajaran

Metode penelitian pada dasarnya merupakan cara ilmiah untuk mendapatkan data dengan tujuan dan kegunaan tertentu. lebih lanjut Sugiono menjelaskan bahwa ada empat kata kunci yang perlu diperhatikan yaitu, cara ilmiah, data tujuan dan kegunaan (Sugiyono 2016). Sedangkan pendapat lainnya mengatakan bahwa desain penelitian bagaikan sebuah peta jalan bagi peneliti yang menuntun serta menentukan arah berlangsungnya proses penelitian secara benar dan tepat sesuai dengan tujuan yang telah ditetapkan, tanpa desain yang benar seorang 
peneliti tidak akan dapat melakukan penelitian dengan baik karena yang bersangkutan tidak mempunyai pedoman arah yang jelas Sarwono (Hidayat 2012). Pengertian penelitian tindakan kelas yang dikemukakan oleh Kemmis adalah bentuk penyelidikan reflektif diri yang dilakukan oleh peserta dalam situasi sosial (termasuk pendidikan) untuk meningkatkan rasionalitas dan keadilan praktik sosial atau pendidikan mereka sendiri, pemahaman mereka tentang praktik ini, dan situasi di mana praktik tersebut dilakukan. di luar. Pemberdayaan yang paling rasional adalah ketika dilakukan oleh partisipan secara kolaboratif, meskipun seringkali dilakukan oleh individu, dan terkadang bekerja sama dengan "orang luar" (Sugiyono 2016).

Pendekatan penelitian yang digunakan dalam penelitian ini adalah pendekatan penelitian kuantitatif karena metode ini telah memenuhi kaidah-kaidah ilmiah yaitu konkrit, empiris, objektif terukur, rasional dan sistematis. Metode penelitian ini disebut metode kuantitatif karena data penelitian berupa angka-angka dan analisis menggunakan statistik. Penelitian tindakan kelas terdapat empat tahapan sebagai berikut:

\section{Perencanaan}

Berdasarkan identifikasi masalah yang dilakukan pada tahap pra PTK, rencana tindakan ini adalah segala hal yang mencakup tindakan secara terperinci. Perencanaan tindakan meliputi materi atau bahan ajar, rencana pengajaran yang mencakup metode, model, pendekatan serta teknik atau instrumen observasi atau evaluasi.

\section{Pelaksanaan Tindakan}

Tahap kedua ini merupakan tahap penerapan dalam pelaksanaan dari perencanaan yang telah dibuat. Tahap ini dilakukan di dalam kelas. Pelaksanaan tindakan ini adalah realisasi dari teoriteori berupa model, metode, ataupun pendekatan dalam pelaksanaan kegiatan belajar mengajar yang tentu mengacu pada kurikulum yang berlaku. Diharapkan dari pelaksanaan dari perencanaan dapat meningkatkan hasil belajar siswa.

\section{Pengamatan}

Kegiatan pengamatan atau observasi ini dilakukan ketika pelaksanaan tindakan dari perencanaan yang sebelumnya dirancang. Data yang dikumpulkan pada tahap ini menguraikan tentang hasil dari perencanaan yang dilaksanakan melalui tindakan dengan bantuan alat atau instrumen observasi yang dikembangkan oleh peneliti. dalam tahap ini guru sebagai seorang peneliti di dalam kelas bisa dibantu oleh pengamat dari luar atau teman sejawat.

\section{Refleksi}

Refleksi adalah tahapan dalam kegiatan memproses data yang didapatkan saat melaksanakan pengamatan atau observasi. Data yang didapat kemudian ditafsirkan, dianalisis dan disintesis. Dalam proses ini semua pengalaman, pengetahuan dan teori-teori instruksional peneliti yang 
PTK, Vol.2 No.2 2022

ISSN: 2747-1977 (Print) / 2747-1969 (Online)

DOI: https://doi.org/10.53624/ptk.v2i2.53

relevan dengan tindakan kelas menjadi bahan pertimbangan dan perbandingan sehingga dapat ditarik suatu kesimpulan yang tepat berdasarkan bukti data yang diperoleh.

Dengan demikian empat tahapan di atas membentuki di sebuah siklus. Di dalam penelitian tindakan kelas biasanya terdapat lebih dari satu siklus, siklus akan berhenti apabila hasil yang diharapkan sudah tercapai. Pada penelitian ini penulis menggunakan dua siklus yaitu:

Siklus I

a) Perencanaan

Tahap perencanaan dalam siklus ini meliputi penyusunan antara lain:

Silabus, RPP yang dirancang dengan pemilihan model studysater, metode ceramah, diskusi dan tanya jawab, dan pendekatan saintifik berbasis TPACK, serta pemilihan media dan pembuatan evaluasi untuk mengukur kemampuan yang dicapai siswa.

b) Pelaksanaan

Pelaksanaan dalam penelitian yang dilakukan oleh guru berdasarkan RPP yang telah disusun. Dan langkah-langkah pelaksanaan pembelajaran berdasarkan kegiatan di dalam RPP

c) Observasi

Observasi dilakukan oleh supervisor. Pengamatan dilakukan selama proses pembelajaran dalam jaringan. Supervisor masuk ke dalam kelas virtual Google Meet dari link yang sudah dibagikan. Pengamatan dilakukan dengan mencatat semua kejadian yang yang berlangsung saat pembelajaran. Pengamatan ini dilakukan dari awal penyampaian kegiatan pembelajaran antara lain kegiatan awal yang dilakukan 10 menit melalui membuka kelas, mengucapkan salam, berdoa dan sebagainya. Selanjutnya kegiatan inti yaitu apersepsi, penyampaian materi dan kegiatan penutup meliputi evaluasi, dan doa penutup.

d) Refleksi

Hasil pelaksanaan penelitian siklus I dikumpulkan dan dianalisis. Dari hasil evaluasi si guru dapat mengetahui peningkatan hasil belajar siswa dengan menggunakan model pembelajaran Studysaster pada pembelajaran daring dalam upaya meningkatkan hasil belajar bahasa Indonesia materi iklan media cetak dan elektronik. Ketercapaian dari hasil penelitian siklus I peserta didik mendapatkan nilai di atas 74 sebesar $40 \%$. Adapun indikator keberhasilan yaitu peserta didik mendapatkan nilai di atas 74 mencapai $70 \%$.

Siklus II

a) Perencanaan

Pada tahap perencanaan dalam siklus II meliputi penyusunan rencana pelaksanaan pembelajaran dengan models Studysaster, metode ceramah, diskusi dan tanya jawab, pendekatan saintifik 
berbasis TPACK, peserta pemilihan media dan pembuatan evaluasi untuk mengukur kemampuan yang dicapai siswa. Penyusunan rencana pembelajaran yang dirancang hampir sama dengan tahap perencanaan pada siklus I. Diharapkan dalam penyusunan perencanaan pembelajaran dengan strategi yaitu pakaian model pembelajaran studysaster yang digunakan dapat meningkatkan hasil belajar siswa pada mata pelajaran bahasa Indonesia materi iklan media cetak dan elektronik.

\section{b) Observasi}

Observasi dilakukan oleh supervisor. pengamatan dilakukan dengan mencatat semua hal-hal penting yang terjadi pada saat pembelajaran berlangsung dalam siklus II. Pengamatan dilakukan dari awal pembelajaran, hampir sama seperti Pada siklus I. Kegiatan ini dilakukan untuk mengetahui kesesuaian proses pembelajaran dengan rencana yang telah disusun sebelumnya.

c) Refleksi

Hasil pelaksanaan penelitian siklus II dikumpulkan dan dianalisis. dari hasil evaluasi ini guru dapat mengetahui peningkatan hasil belajar siswa dengan menggunakan model pembelajaran Studysaster pada mata pelajaran Bahasa Indonesi materi iklan media cetak dan Elektronik. Pada siklus II nilai di atas 74 telah dicapai sebesar $57 \%$.

\section{Teknik Analisis Data}

Data yang dianalisis dalam penelitian ini adalah hasil evaluasi mata pelajaran bahasa Indonesia materi iklan media cetak dan elektronik. Data yang dianalisis dalam penelitian ini adalah hasil evaluasi mata pelajaran bahasa Indonesia materi iklan media cetak dan elektronik. Teknik analisis data merupakan teknik cara menganalisis data penelitian termasuk alat-alat statistika yang relevan digunakan dalam penelitian. Setelah data dikumpulkan data itu perlu diseleksi tingkat reliabilitas dan validitasnya. Data yang memiliki reliabilitas dan validitas rendah digugurkan. Di samping itu data yang kurang lengkap tidak perlu disertakan dalam unit analisis.

Metode yang digunakan dalam penelitian ini adalah metode deskriptif analitis komparatif. Metode dekkriptif merupakan metode yang digunakan untuk memecahkan masalah aktual dengan cara mengumpulkan data, menyusun, mengklasifikasikan, menganalisis, serta menginterpretasikannya Ahmadi dan Narbuko (Huri 2014).

Adapun pendapat lain yang mengatakan bahwa metode komparatif adalah metode yang bersifat membandingkan Hasyim (Huri 2014), maka Dalam penelitian ini akan membandingkan hasil rata-rata nilai kemampuan siswa pada kondisi sebelum tindakan dan setelah tindakan pada siklus I dan siklus II. 
PTK, Vol.2 No.2 2022

ISSN: 2747-1977 (Print) / 2747-1969 (Online)

DOI: https://doi.org/10.53624/ptk.v2i2.53

Untuk analisis data dengan teknik deskriptif komparatif dengan cara:

a. Melalui Ulangan atau Tes Formatif

Penilaian tes hasil belajar digunakan nilai rata-rata dengan rumus sebagai berikut (Sudjana dalam B 2012):

$$
N R=\frac{\sum X}{N}
$$

Keterangan :

$\mathrm{NR}=$ nilai rata-rata

$\mathrm{x}=$ jumlah nilai

$\mathrm{N}=$ jumlah siswa

b. Ketuntasan Belajar

Ketuntasan belajar dapat dikategorikan menjadi dua yaitu ketuntasan belajar perorangan dan ketuntasan belajar secara klasikal. Seorang peserta didik dapat dikatakan tuntas belajar apabila peserta didik tersebut telah mencaapai atau melampaui dari kriteri ketuntasan minimal yaitu 75 , dan yang dapat disebut dengan kelas tuntas belajaar adalah jika daya serap kelas dapat mencapai atau lebih dari $70 \%$ dari $100 \%$. Sedangkan Ketuntasan Belajar Secara Klasikal dihitung dengan rumus (Sudjana dalam B 2012):

$\mathrm{KB}=\frac{\mathrm{N}^{\prime}}{\mathrm{N}} \times 100 \%$

Keterangan :

$\mathrm{KB}=$ ketuntasan belajar secara klasikal

$\mathrm{N}^{\prime}=$ jumlah siswa yang nilainya $\geq 75$

$\mathrm{N}=$ jumlah siswa keseluruhan.

\section{HASIL DAN PEMBAHASAN}

\section{A. Siklus I}

Penelitian tindakan kelas ini dilaksanakan berdasarkan kondisi awal siswa kelas 5 SD Kyai Ibrahim Surabaya Pada siklus I masih banyak siswa yang mendapatkan nilai dibawah Kriteria Ketuntasan Minimal atau dibawah nilai 75, sehingga peserta didik yang mencapai nilai di atas 
74 hanya sebesar $57 \%$ atau 16 siswa yang mencapai nilai diatas 74 . Sedangkan yang diharapakan $70 \%$ dari jumlah siswa kelas 5C.

Dari hasil evaluasi masih banyak terdapat nilai peserta didik dibawa kriteria ketuntasan minimal, maka peneliti yang juga bertindak sebagai guru perlu menyusun suatu model pembelajaran yang lain sehingga dapat meningkatkan kemampuan siswa dalam materi iklan media cetak dan elektronik dalam mata pelajaran Bahasa Indonesia. Jika dalam pelaksanaan pembelajaran siklus I hasil yang diperoleh kurang maksimal, maka peneliti perlu mengadakan evaluasi ulang dan tindak lanjut serta perbaikan pada siklus II.

\section{Perencanaan}

Perencanaan penelitian yang dilakukan pada siklus I terdiri atas penyusunan rencana persiapan pembelajaran (RPP), menyiapkan penunjang sumber belajar antara lain buku paket tematik kelas 5 SD, media PPT, instrumen lembar kerja peserta didik, dan instrumen evaluasi untuk mengukur kemampuan atau keberhasilan siswa.

2. Pelaksanaan Tindakan

Pelaksanaan proses pembelajaran Pada siklus 1 dilaksanakan pada hari Selasa tanggal 12 Januari 2021, dengan alokasi waktu 2 x 35 menit yang dimulai pada pukul 08.00 dan peneliti bertindak sebagai guru kelas.

Guru memulai pelajaran dengan mempersiapkan perangkat pembelajaran terlebih dahulu. Untuk perangkat keras nya berupa laptop, hp, RPP, alat tulis, buku guru. Sedangkan perangkat lunaknya berupa file RPP, media PPT, flipbook, soal yang telah dibagikan lewat link office 365 , lkpd yang dibagikan melalui link Google form. Dalam proses pembelajaran guru menggunakan 3 tahapan yaitu kegiatan awal 10 menit, Kegiatan inti 50 menit, dan kegiatan penutup 10 menit.

3. Observasi

Observasi dilakukan selama pembelajaran berlangsung, observasi atau pengamatan ini meliputi : sikap siswa dalam mengikuti pembelajaran, respon atau tanggapan siswa terhadap pembelajaran yang diberikan oleh guru. Pengamatan ini berkaitan dengan tindakan guru dan hasil belajar siswa.

\section{Refleksi}

Berdasarkan hasil pelaksanaan siklus I, belum terlihat hasil yang maksimal karena jumlah siswa yang nilainya diatas 74 hanya mencapai 57\% atau sebanyak 16 siswa, dan masih 12 siswa yang yang nilainya di bawah kriteria ketuntasan minimal atau KKM.

Berdasarkan alasan tersebut peneliti perlu mengadakan perbaikan proses pembelajaran Pada siklus II dengan melakukan identifikasi kekurangan atau kelemahan pembelajaran Pada siklus I, maka guru dapat melakukan perbaikan pembelajaran dengan menggunakan metode atau model yang lain. Pada perencanaan pelaksanaan pembelajaran siklus II guru akan menggunakan model 
PTK, Vol.2 No.2 2022

ISSN: 2747-1977 (Print) / 2747-1969 (Online)

DOI: https://doi.org/10.53624/ptk.v2i2.53

pembelajaran Studysaster, yang mana pembelajaran ini menggunakan pendekatan saintifik berbasis TPACK.

\section{B. Siklus II}

Berdasarkan hasil pengamatan dari nilai yang diperoleh siswa, masih banyak yang mendapatkan nilai dibawah 75 atau di bawah kriteria ketuntasan minimal atau KKM, maka peneliti yang juga bertindak sebagai guru perlu melakukan perbaikan dalam penyusunan rencana pelaksanaan pembelajaran yaitu guru mencoba menggunakan model pembelajaran Studysaster yang bertujuan untuk meningkatkan hasil belajar peserta didik pada materi iklan media cetak dan elektronik pembelajaran Bahasa Indonesia. Penyusunan an perencanaan observasi dan refleksi sebagai berikut:

1. Perencanaan

Rencana tindakan Pada siklus 2 dilakukan dengan mempersiapkan semua perangkat pembelajaran baik perangkat keras dan perangkat lunak antara lain : laptop, hp, buku tematik, modul Bahasa Indonesia, RPP, alat tulis, lembar kerja peserta didik, lembar evaluasi peserta didik, instrumen penilaian, kisi-kisi pembuatan soal evaluasi dan LKPD, media PPT, flipbook, aplikasi Google form untuk LKPD dan aplikasi office 365 untuk media evaluasi serta alat-alat lainnya yang mendukung pembelajaran bahasa Indonesia materi iklan media cetak dan elektronik, agar peserta didik dapat tertarik dan lebih memahami tentang materi tersebut.

2. Pelaksanaan Tindakan

Pelaksanaan tindakan Pada siklus II, proses pembelajaran di laksanakan pada hari Rabu tanggal 13 Januari 2021, dengan alokasi waktu 2 x 35 menit atau 2 jam pembelajaran. Peneliti bertindak sebagai guru kelas sedangkan yang bertindak sebagai observer adalah supervisor II. Proses kegiatan belajar diamati secara langsung dari mulai kegiatan awal, kegiatan inti, kegiatan penutup di dalam kelas virtual oleh observer atau pengamat yang sebelumnya diberi link google meet terlebih agar dapat bergabung di kelas virtual.

\section{Observasi}

Kegiatan observasi yang dilakukan bertujuan untuk mengamati peningkatan dan mengetahui kesesuaian kegiatan yang dilakukan guru dengan rencana pelaksanaan pembelajaran yang telah disusun sebelumnya dan mengamati sikap peserta didik, yang berupa respon atau tanggapan anne-marie materi yang diberikan oleh guru. Untuk pengamatan hasil belajar siswa, dapat dilihat dari hasil evaluasi yang dikerjakan oleh peserta didik. 


\section{Refleksi}

Setelah mengamati siklus 2 dari hasil belajar siswa yang diperoleh, terdapat peningkatan hadap hasil belajar Bahasa Indonesia materi iklan media cetak dan elektronik. Dari data hasil evaluasi siswa diperoleh 21 siswa nilainya mencapai dan melampaui kriteria ketuntasan minimal. Sedangkan kan 7 siswa nilainya masih dibawah kriteria ketuntasan minimal atau KKM.

\section{Pembahasan Hasil Penelitian Perbaikan Pembelajaran}

Berdasarkan hasil yang didapat pada siklus I dapat disimpulkan bahwa kemampuan siswa pada pembelajaran Bahasa Indonesia materi iklan media cetak dan elektronik mengalami peningkatan anne-marie mulai $57 \%$ menjadi $75 \%$. Adanya peningkatan hasil pembelajaran tersebut dikarenakan guru menggunakan model pembelajaran Studysaster pada pembelajaran Bahasa Indonesia materi iklan media cetak dan elektronik. model pembelajaran yang digunakan oleh guru ternyata memiliki dampak atau pengaruh yang positif dalam upaya peningkatan hasil belajar siswa. Hal ini dapat dilihat dari tingkah laku atau sikap siswa ketika mengikuti pembelajaran siswa terlihat aktif dan menikmati dalam proses pembelajaran tersebut. Pada siklus II ini diperoleh ketuntasan klasikal sebesar $81 \%$ melebihi batas minimal ketuntasan klasikal yang telah ditentukan sebelumnya sebesar 75\%, sehingga peneliti merasa tidak perlu melanjutkan Pada siklus berikutnya atau siklus III.

\section{KESIMPULAN}

Dari hasil kegiatan pembelajaran yang telah dilaksanakan selama dua siklus, dan berdasarkan seluruh pembahasan analisis yang telah dilaksanakan dapat disimpulkan bahwa proses pembelajaran dengan menggunakan model Studysaster ternyata memiliki dampak yang yang positif dalam upaya meningkatkan hasil belajar atau prestasi peserta didik yang ditandai dengan adanya peningkatan hasil belajar siswa dalam setiap siklus. Siklus I sebesar 57\% dan siklus II sebesar $75 \%$. Selain itu, penerapan model pembelajaran itu Studysaster dalam pembelajaran memiliki pengaruh yang positif, yakni dapat meningkatkan hasil belajar atau prestasi peserta didik yang dibuktikan dari hasil evaluasi yang menunjukkan bahwa siswa lebih memahami materi iklan media cetak dan elektronik dalam pembelajaran bahasa Indonesia di mana pada siklus I rata-rata hasil belajar siswa diperoleh sebesar $71,4 \%$ dan pada siklus II sebesar $82,2 \%$. 
PTK, Vol.2 No.2 2022

ISSN: 2747-1977 (Print) / 2747-1969 (Online)

DOI: https://doi.org/10.53624/ptk.v2i2.53

\section{DAFTAR PUSTAKA}

B., N. A. 2012. Penerapan Model Pembelajaran Kooperatif Tipe Examples Nonj Examples Dengan Menggunakan Alat Peraga Untuk Meningkatkan Hasil Belajar Siswa Di Kelas VIII SMPN 1 Argamakmur. Jurnal Exacta, 24-35.

Hidayat, A. 2012, Mei 12. Penjelasan Desain Penelitian. Diambil kembali dari statistikian.com: https://www.statistikian.com/2012/05/desain-penelitian-pengantar.html

Huri, D. 2014. Penguasaan Kosa Kata Kedwibahasaan Antara Bahasa Sunda Dan Bahasa Indonesia Pada Anak-anak (Sebuah Analisis Deskriptif Komparatif). Jurnal Pendidikan UNSIKA, 59-77.

Nurhasanah, A., Maryuni, Y., \& Ramadhan, A. 2020. Pemanfaatan Vlog Sejarah Sebagai Media Alternatif Di Era Covid-19. Jurnal Untirta, 414-424.

S, O. F., \& Winata, H. 2018. Regulasi diri (pengaturan diri) sebagai determinan hasil belajar siswa sekolah menengah kejuruan. Jurnal Pendidikan Manajemen Perkantoran, 36-43.

Sugiyono. 2016. Metode Penelitian Kuantitatif, Kualitatif Dan R \& D. Bandung: Alfabeta.

Sujatmoko, E. 2010. Hak Wrga Negara Dalam Memperoleh Pendidikan. Jurnal Konstitusi, 182211.

Widyasari, E. 2020. Model Pembelajaran Studysaster Dalam Upaya Meningkatkan Imunitas pada Pandemi Covid-19. Social, Humanities, and Educational Studies (SHEs): Conference Series, 32-37. 